Journal of Didactic Mathematics

2020, 1(2), 85-96

Doi: $10.34007 / j \mathrm{dm} . v 1 \mathrm{i} 2.304$

(\#ttps://mahesainstitute.web.id/ojs2/index.php/jdm

(10) jou

journalofdidacticmathematics@gmail.com

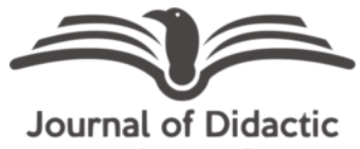

Mathematics

\title{
Perbedaan peningkatan kemampuan pemecahan masalah matematis dengan pendekatan contextual teaching and learning di kelas X SMA Negeri 2 Pematangsiantar
}

\author{
Winmery Lasma Habeahan* \\ AMIK D3 Medicom, Medan, Sumatera Utara, Indonesia, 20225 \\ *Corresponding Author: winmeryhabeahan@gmail.com
}

\begin{abstract}
The purpose of this study was to determine the differences in the improvement of students' mathematical problem solving abilities with the Contextual Teaching and Learning approach in the material of the twovariable linear equation system in class X SMA Negeri 2 Pematangsiantar. This study used an experimental method with the aim of being in accordance with the previous statement to determine the difference in students' mathematical problem solving abilities with a contextual approach and an expository approach, with a randomized pretest-posttest control group design. The average increase in problem-solving abilities in the control class was 0.1688 while the increase in problem-solving abilities in the experimental class was 0.0085 . By using the t-test (SPSS), with a value of Fcount $=10.907$ and a significant level of 0.05 , a significant probability is obtained $0.002<0.05$, it can be concluded that there is a difference in normalized gain or an increase in problem solving ability with conventional and contextual approaches. Based on the average gain of the control and experimental classes, the increase in the control class using the conventional approach is higher than the experimental class with the contextual approach. The difference in increasing problem-solving abilities in conventional classrooms is possible due to differences in students' entry-level abilities, which can be seen in the average pretest of each class.
\end{abstract}

Historis Artikel:

Diterima: 2 Agustus 2020

Direvisi: 24 Agustus 2020

Disetujui: 28 Agustus 2020

\section{Keywords:}

Problem Solving Ability, Contextual Teaching

Learning

Sitasi: Habeahan, W. L. (2020) Perbedaan peningkatan kemampuan pemecahan masalah matematis dengan pendekatan contextual teaching and learning di kelas X SMA Negeri 2 Pematangsiantar. Journal of Didactic Mathematics, 1(2), 85-96. Doi: 10.34007/jdm.v1i2.304

\section{PENDAHULUAN}

Pendidikan sangat penting untuk menunjang proses peningkatan kemampuan dan pengetahuan seseorang. Pendidikan juga mampu memanusiakan manusia dan menghasilkan manusia yang berkualitas. Salah satu hal yang menunjang kualitas pendidikan adalah proses belajar mengajar.

Belajar dan mengajar dilakukan untuk mewujudkan suatu tujuan tertentu yang telah ditetapkan sebelum dilaksanakan proses belajar dan mengajar. Dengan adanya proses belajar dan mengajar diharapkan kemampuan siswa akan lebih meningkat lagi. Fitrah (2017) mengungkapkan bahwa belajar dimaknai sebagai proses perubahan perilaku sebagai hasil interaksi dengan lingkungannya. Perubahan perilaku terhadap hasil belajar bersifat continue, fungsional, positif, aktif, dan terarah.

Matematika merupakan ilmu yang sangat penting untuk mengembangkan daya nalar dan kemampuan pemecahan masalah siswa sehingga matematika dipelajari dari sekolah dasar hingga perguruan tinggi. Afifah (2012) mengungkapkan bahwa pentingnya matematika dalam pembelajaran mulai dari jenjang sekolah dasar sampai perguruan tinggi yang berfungsi dalam 
mengembangkan daya nalar kemampuan berpikir.

Cornelius (dalam Abdurrahman, 2012: 204) mengungkapkan bahawa lima alasan perlunya belajar matematika karena matematika merupakan (1) sarana berpikir yang jelas dan logis, (2) sarana untuk memecahkan masalah kehidupan sehaari-hari, (3) sarana mengenal pola-pola hubungan dan generalisasi pengalaman, (4) sarana untuk mengembangkan kreativitas, dan (5) sarana untuk meningkatkan kesadaran terhadap perkembangan budaya. Diharapkan dengan belajar matematika siswa tidak hanya semakin mampu dalam berhitung tetapi mampu berpikir dengan jelas serta logis, mampu mengembangkan kreativitas dan mampu memecahkan masalah dalam kehidupan sehari-hari.

Berdasarkan hasil belajar matematika, Lerner (dalam Abdurrahman 2012: 253) mengemukakan bahwa: "Kurikulum bidang studi matematika hendaknya mencakup tiga elemen, (1) konsep, (2) keterampilan, dan (3) pemecahan masalah". Sehingga pemecahan masalah merupakan bagian dari kurikulum matematika yang sangat penting karena dalam proses pembelajaran maupun penyelesaiannya, siswa dimungkinkan memperoleh pengalaman menggunakan pengetahuan serta keterampilan yang sudah dimiliki untuk diterapkan pada pemecahan masalah yang bersifat tidak rutin.

Kenyataan yang terlihat di lapangan, siswa hanya menghafal konsep dan kurang mampu menggunakan konsep tersebut jika menemui masalah dalam kehidupan yang nyata yang berhubungan dengan konsep yang dimiliki. Lebih jauh lagi bahkan siswa kurang mampu menentukan masalah dan merumuskannya. Hal itu karena mereka kurang memahami dan mengerti secara mendalam pengetahuan yang bersifat hafalan tersebut.

Ketika mengikuti proses belajar mengajar, penulis mengamati bahwa banyak siswa tidak memperhatikan dan mengikuti dengan baik proses belajar matematika di kelas. Tidak ada yang bertanya atau sebagian besar siswa tidak aktif, jarang di antara mereka yang mau bertanya, ataupun memberi tanggapan. Ketika memberikan tugas pertama, lebih banyak yang tidak mengerjakan daripada mengerjakan. Mereka tidak berminat mengerjakan tugas tersebut. Hasil belajar dan kemampuan pemecahan masalah sangat rendah.

Untuk melihat bagaimana kemampuan pemecahan masalah siswa, penulis melakukan observasi berupa pemberian tes diagnostik ke siswa kelas X SMA Negeri 2 Pematangsiantar, tes yang diberikan berupa tes berbentuk uraian untuk melihat kemampuan siswa dalam memecahkan masalah matematika. Hasil tes diagnostik yang dilakukan pada 30 siswa tersebut menunjukkan bahwa 4 siswa $(13 \%)$ memiliki nilai $\geq 75$ orang, 4 siswa yang memiliki nilai diantara 74 dengan $60(13 \%)$ dan 22 orang siwa memiliki nilai $\leq 59$ (73,33\%). Dari hasil pekerjaan siswa diketahui bahwa siswa tidak memahami masalah yang diberikan sehingga yang terjadi siswa tidak mengerti menyusun langkah awal penyelesaian seperti mengumpulkan informasi yang diperoleh dari masalah tersebut dan siswa kesulitan merencanakan penyelesaiannya dan selanjutnya salah atau tidak mampu mengerjakannya (contoh hasil kerja siswa terdapat pada gambar 1).

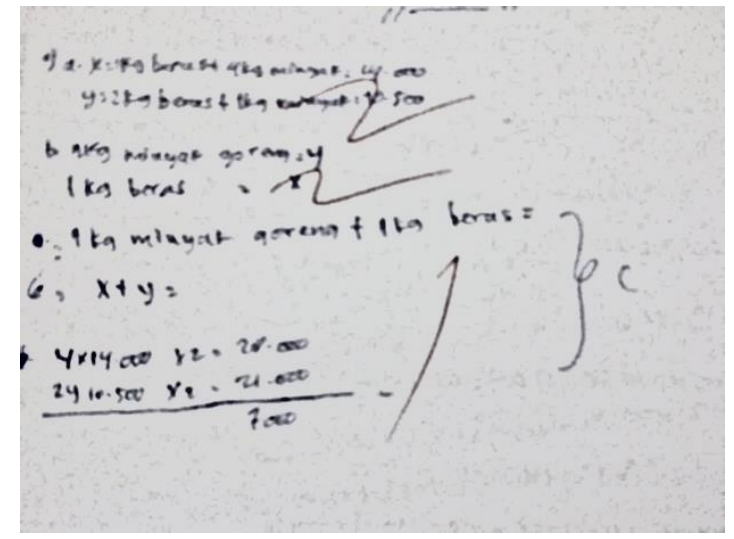

Gambar 1. Tes Observasi Kemampuan Pemecahan Masalah Siswa 
Perbedaan peningkatan kemampuan pemecahan masalah matematis dengan...

Kenyataan yang terlihat di lapangan, siswa hanya menghafal konsep dan kurang mampu menggunakan konsep tersebut jika menemui masalah dalam kehidupan nyata yang berhubungan dengan konsep yang dimiliki. Lebih jauh lagi bahkan siswa kurang mampu menentukan masalah dan merumuskannya. Hal itu karena mereka kurang memahami dan mengerti secara mendalam pengetahuan yang bersifat hafalan tersebut.

Model pembelajaran CTL merupakan konsep belajar yang membantu guru mengaitkan antara materi yang diajarkan dengan situasi dunia nyata dan dapat mendorong siswa membuat hubungan antara pengetahuan yang dimiliki dan penerapannya dalam kehidupan sehari-hari. Dengan membuat hubungan antara pengetahuan atau konsep yang telah dimiliki oleh siswa serta penerapannya dalam kehidupan sehari-hari, maka siswa akan mudah memahami konsep. Dengan model pembelajaran CTL maka siswa akan bekerja dan mengalami, bukan transfer pengetahuan dari guru ke siswa semata. Strategi lebih dipentingkan daripada hasilnya. Sehingga pengetahuan dan ketrampilan yang diperoleh datang dari proses penemuan sendiri dan bukan dari "apa kata guru”.

Pendekatan kontekstual merupakan strategi yang dikembangkan dengan tujuan agar pembelajaran berjalan lebih produktif dan bermakna, tanpa harus mengubah kurikulum dan tatanan yang ada. Dengan siswa diajak bekerja dan mengalami, siswa akan mudah memahami konsep suatu materi dan nantinya diharapkan siswa dapat menggunakan daya nalarnya untuk menyelesaikan masalah-masalah yang ada.

Berdasarkan uraian di atas, bahwa kemampuan pemecahan masalah merupakan tujuan pembelajaran matematika yang sangat penting, dan salah satu pembelajaran yang dapat meningkatkan kemampuan pemecahan masalah siswa adalah pendekatan kontekstual. Oleh karena itu, penulis tertarik untuk melakukan penelitian dengan judul "Perbedaan Peningkatan Kemampuan Pemecahan Masalah Matematika dengan Pendekatan Contextual Teaching and Learning di Kelas X SMA Negeri 2 Pematangsiantar.”

\section{METODE}

Populasi dalam penelitian ini adalah seluruh siswa kelas X SMA Negeri 2 Pematangsiantar yang terdiri dari 10 kelas paralel dengan rata-rata jumlah siswa per kelas adalah 30 orang. Penelitian ini dilakukan pada dua kelas yang mewakili populasi dan memiliki karakteristik yang sama. Pengambilan sampel dan penentuan kelas sampel dalam penelitian ini diambil secara acak, yaitu menggunakan teknik random sampling. Kelas X-10 sebagai kelas kontrol dan kelas X-3 sebagai kelas eksperimen.

Penelitian ini menggunakan metode eksperimen dengan tujuan sesuai untuk mengetahui peningkatan perbedaan kemampuan pemecahan masalah matematika siswa dengan pendekatan kontekstual dan pendekatan ekspositori, dengan desain randomized pretest-postest control group design. Kelas eksperimen diberi pemebelajaran dengan pendekatan kontekstual sedangkan kelompok kedua diberikan perlakuan dengan pembelajaran biasa. Dengan demikian design eksperimen dalam penelitian ini dapat digambarkan sebagai berikut:
A
$\mathrm{O}_{1}$
$\mathrm{O}_{2}$
(Dicky, 2019: 196)

A

Keterangan:

A = pemilihan kelas secara acak

O1 = Tes awal (pre test)

$\mathrm{X}=$ Pembelajaran dengan pendekatan kontekstual

$\mathrm{O}_{2}=$ Tes akhir (post test)

Penelitian ini terdiri dari 3 tahap, yaitu:

1. Tahap Persiapan

Pada tahap ini dilakukan beberapa kegiatan yaitu mengembangkan perangkat pembelajaran (RPP dan LAS) 
2. Tahap Pelaksanaan

Tahap ini diawali dengan pemberian pretes (tentang kemampuan pemecahan masalah matematika siswa) sebelum pembelajaran terhadap materi baru diberikan kepada siswa. Pretes diberikan kepada kelompok eksperimen dan kelompok kontrol, dengan tujuan apakah kedua kelompok tersebut memiliki kemampuan yang homogen. Setelah diketahui kemampuan kedua kelompok homogen maka dilanjutkan dengan kegiatan melaksanakan pembelajaran di kelas sesuai dengan jadwal yang telah ditetapkan.

3. Tahap Analisis Data

Pengolahan data dalam pengujian hipotesis antara lain dengan uji normalitas dan homogenitas, selanjutnya dilanjutkan uji $\mathrm{t}$ dan anova satu jalur seluruh perhitungan statistik menggunakan bantuan program komputer SPSS 15 dan program Microsoft Excel.

a. Menghitung rata-rata dan standar deviasi skor pretes

Skor pretes dicari rata-rata dan deviasi standarnya untuk mengetahui gambaran tentang kemampuan pemecahan masalah matematika siswa yang diberi pendekatan CTL dan pembelajaran biasa sebelum diberikan pembelajaran.

b. Menghitung rata-rata dan standar deviasi skor protes

Skor pretes dicari rata-rata dan deviasi standarnya untuk mengetahui gambaran tentang kemampuan pemecahan masalah matematika siswa yang diberi pendekatan CTL dan pembelajaran biasa sesudah diberikan pembelajaran.

c. Menghitung skor Gain

Untuk melihat peningkatan kemampuan pemecahan masalah matematika siswa setelah pembelajaran dengan pendekatan CTL dan pembelajaran biasa, maka dilakukan perhitungan terhadap skor gain. Richard Hake (dalam Nihayah, 2017: 12) membuat formula untuk menjelaskan gain secara proposional, yang disebut dengan normalized gain (gain ternormalisasi). Gain ternormalisasi (g) adalah proporsi antara gain aktual (posttestpretest) dengan gain maksimal yang dapat dicapai. Rumusnya adalah:

$g=\frac{\text { nilai postest }- \text { nilai pretest }}{\text { nilai ideal }- \text { nilai pretest }}$

Skor gain ternormalisasi dapat dikelompokkan ke dalam tiga kategori, yaitu: rendah, sedang dan tinggi. Kategori sesuai dengan nilai g adalah sebagai berikut:

Tabel 1. Kriteria gain ternormalisasi

\begin{tabular}{ll}
\hline$g<0,3$ & Rendah \\
\hline $0,3 \leq g<0,7$ & Sedang \\
\hline$g \geq 0,7$ & Tinggi \\
\hline
\end{tabular}

d. Uji Homogenitas varians dengan menggunakan rumus:

$F=\frac{S_{\text {besar }}^{2}}{S_{\text {kecil }}^{2}}=\frac{S_{b}^{2}}{S_{k}^{2}} \quad$ (Qurnia, 2017: 173)

Dengan:

$\mathrm{F}=$ homogenitas varians

$S_{b}^{2}=$ varians terbesar

$S_{k}^{2}=$ varians terkecil

Uji homogenitas dilakukan dengan tujuan melihat homogenitas atau kesamaan beberapa bagian sampel atau seragam tidaknya variansi sampel - sampel yaitu apakah mereka berasal dari populasi yang sama. Langkah-langkah yang dilakukan dalam pengujian homogenitas sebagai berikut:

d.1. Merumuskan hipotesis

$$
\begin{aligned}
& H_{0}: \sigma_{e}^{2}=\sigma_{k}^{2} \\
& H_{a}: \sigma_{e}^{2} \neq \sigma_{k}^{2}
\end{aligned}
$$


Perbedaan peningkatan kemampuan pemecahan masalah matematis dengan...

d.2. Menentukan tingkat keberartian dengan mengambil $\alpha$ sebesar 0,05. Menentukan kriteria pengujian dengan aturan, menerima $H_{0}$ apabila nilai $F_{\text {hitung }} \leq F_{\text {tabel }}$ dan derajat kebebasan $d k_{1}=n-1$ dan $d k_{2}=n-1$ sehingga nilai $F_{\text {tabel }}=$ $F_{0,05}\left(n_{1}-1\right)\left(n_{2}-1\right)$ pada kondisi lain $H_{0}$ ditolak. Uji homogenitas dilakukan dengan uji Levene statistik dengan kriteria nilai signifikan Levene lebih besar dari nilai signifikansi 0,05 sehingga $H_{0}$ diterima dalam bentuk lain $H_{0}$ ditolak, artinya bahwa kedua kelompok tidak terdapat perbedaan varians, atau kedua kelompok homogen

e. Uji hipotesis

Penelitian ini ditunjukan untuk menguji perbedaan dua rata-rata variabel yang berhubungan (dependent mean). Oleh karena itu, hipotesis statistik yang harus diuji dirumuskan sebagai berikut:

$H_{0}: \mu_{x}<\mu_{y}$

$H_{a}: \mu_{x} \geq \mu_{y}$

$H_{0}$ : Tidak ada perbedaan peningkatan yang signifikan kemampuan pemecahan masalah matematika siswa yang diajar dengan pendekatan CTL dan pembelajaran biasa.

$H_{a}$ : Ada perbedaan peningkatan yang signifikan kemampuan pemecahan masalah matematika siswa yang diajar dengan pendekatan CTL dan pembelajaran biasa.

Dengan:

$\mu_{x}$ : kemampuan pemecahan masalah matematika siswa yang diajarkan dengan pendekatan CTL.

$\mu_{y}$ : kemampuan pemecahan masalah matematika siswa yang diajarkan dengan pembelajaran biasa.

Pengujian hipotesis menggunakan program SPSS 15 dengan Levene's test for Equality of $V$ ariances dengan taraf signifikansi 0,05 , kriteria pengujian jika signifikan Levene tes for equality lebih besar dari taraf signifikan 0,05 , tolak $H_{0}$ dalam bentuk lain $H_{0}$ diterima.

Rumus yang digunakan untuk mencari $t_{\text {hitung }}$ adalah:

1. Jika kedua kelompok berdistribusi normal dan homogen, maka uji statistik yang digunakan adalah uji- t dengan rumus sebagai berikut:

$t=\frac{\bar{X}-\bar{Y}}{\sqrt{S_{x-y}^{2}\left(\frac{1}{n_{x}}+\frac{1}{n_{y}}\right)}} \quad$ (Ruseffendi, 2010: 325)

Dengan $d k=n_{x}+n_{y}-2$ dan

Varian $S_{x-y}^{2}=\frac{\sum(X-\bar{x})^{2}+\sum(Y-\bar{Y})^{2}}{n_{x}+n_{y}-2}$

2. Jika kedua kelompok berdistribusi normal tetapi tidak homogen, maka uji statistik yang digunakan adalah uji - t (uji t'), dengan rumus sebagai berikut:

$$
t^{\prime}=\frac{\overline{X_{1}}-\overline{X_{2}}}{\sqrt{\frac{s_{1}^{2}}{n_{1}}+\frac{s_{2}^{2}}{n_{2}}}} \quad \text { (Sudjana, 2013: 241) }
$$

3. Pengujian normalitas dengan menggunakan program SPSS 15 yakni dengan melibatkan uji Kolmogorov - simirnov adalah suatu tes apakah kedua sampel independen telah ditaruik dari populasi yang sama. Untuk menerapkan tes dua sampel Kolmogorov - simirnov dibuat distribusi frekuensi kumulatif untuk sampel penelitian dengan menggunakan interval-interval yang sama untuk kedua distribusi. Pengujian normalitas memerlukan hipotesis sebagai berikut:

$H_{0}=$ data populasi berdistribusi normal

$H_{a}=$ data populasi tidak berdistribusi normal 
Kriterianya adalah tolak $H_{0}$ apabila populasi berdistribusi normal jika $\mathrm{L}_{0}$ yang diperoleh dari data pengamatan lebih besar dari $\mathrm{L}_{\text {tabel. }}$ Dalam hal ini hipotesis $H_{0}$ diterima atau nilai signifikansi Kolmogorov - simirnov lebih besar dari taraf signifikan 0,05.

\section{HASIL DAN PEMBAHASAN}

Pretest dilaksanakan terhadap siswa kelas X SMA Negeri 2 Pematangsiantar, jumlah siswa kelas kontrol adalah 30 siswa yaitu kelas X-10 dan 30 siswa kelas eksperimen yaitu kelas X-3. Untuk menghindari ketidaktahuan siswa, satu hari sebelum diadakan pretest telah diberitahukan terlebih dahulu melalui guru mata pelajaran matematika yang mengajar di kelas tersebut, dan diminta agar siswa mempelajari dan mempersiapkannya.

Data tes kemampuan pemecahan masalah siswa pada prestest diperoleh dari tes tertulis berbentuk uraian sebanyak 3 soal, dengan skor maksimum untuk keseluruhan adalah 30. Setelah lembar jawaban diperiksa, maka diperoleh skor terendah $\left(X_{\min }\right)$, skor tertinggi $\left(X_{\max }\right)$, skor ratarata $\left(\mathrm{X}_{\text {rata-rata }}\right)$, dan standar deviasi dari kelas eksperimen dan kelas kontrol seperti dideskripsikan pada tabel 2.

Tabel 2. Deskripsi Skor Pretest Kelas Eksperimen dan Kontrol

\begin{tabular}{|c|c|c|c|c|c|c|}
\hline \multicolumn{7}{|c|}{ Descriptives } \\
\hline & \multirow{2}{*}{\multicolumn{2}{|c|}{ Kelas }} & \multicolumn{2}{|c|}{ Eksperimen } & \multicolumn{2}{|c|}{ Kontrol } \\
\hline & & & Statistic & Std. Error & Statistic & Std. Error \\
\hline \multirow[t]{13}{*}{ pretest } & Mean & & 45.1111 & 3.23508 & 49.5556 & 1.84130 \\
\hline & 95\% Confidence & Lower Bound & 38.4946 & & 45.7897 & \\
\hline & Interval for Mean & Upper Bound & 51.7276 & & 53.3214 & \\
\hline & 5\% Trimmed Mean & & 43.8889 & & 48.8272 & \\
\hline & Median & & 40.0000 & & 46.6667 & \\
\hline & Variance & & 313.972 & & 101.711 & \\
\hline & Std. Deviation & & 17.71925 & & 10.08521 & \\
\hline & Minimum & & 20.00 & & 36.67 & \\
\hline & Maximum & & 90.00 & & 76.67 & \\
\hline & Range & & 70.00 & & 40.00 & \\
\hline & Interquartile Range & & 20.83 & & 14.17 & \\
\hline & Skewness & & 1.220 & .427 & 1.081 & .427 \\
\hline & Kurtosis & & 1.177 & .833 & .732 & .833 \\
\hline
\end{tabular}

Dari tabel 2 terlihat skor rata-rata untuk kelas kontrol lebih tinggi dari kelas eksperimen dengan skor tertinggi di kelas kontrol lebih rendah dari pada kelas eksperimen serta skor tertendah kelas kontrol lebih tinggi dari pada kelas eksperimen. Untuk menguji apakah ada perbedaan dari dua rata-rata antara kelas ekperimen dan kontrol, harus diuji dulu normalitas dan homogenitas data. Uji normalitas dan homogenitas dipakai untuk memenuhi syarat uji dua ratarata dengan menggunakan uji-t atau uji statistik parametrik. Hasil perhitungan $\chi^{2}$ dan harga

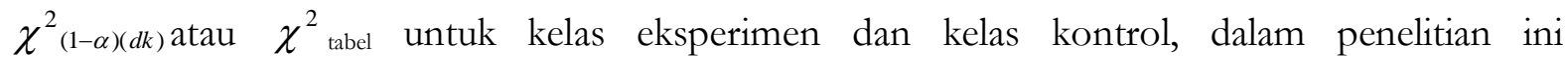
menggunakan uji statistic Kolmogorov-Smirnov pada kedua kelompok, lebih lengkapnya dapat dilihat pada tabel 3 .

Tabel 3. Hasil Uji Normalitas Kelas Eksperimen dan Kelas Kontrol

\section{Tests of Normality}

\begin{tabular}{llrrrrrr}
\hline & & \multicolumn{3}{c}{ Kolmogorov-Smirnov $^{a}$} & \multicolumn{3}{c}{ Shapiro-Wilk } \\
\cline { 3 - 9 } & kelas & Statistic & $\mathrm{df}$ & \multicolumn{1}{c}{ Sig. } & Statistic & $\mathrm{df}$ & \multicolumn{1}{c}{ Sig. } \\
\hline pretest & eks & .158 & 30 & .054 & .883 & 30 & .003 \\
& kontrol & .149 & 30 & .087 & .887 & 30 & .004 \\
\hline
\end{tabular}

a. Lilliefors Significance Correction 
Perbedaan peningkatan kemampuan pemecahan masalah matematis dengan...

Dari tabel 3 terlihat bahwa probabilitas signifikan dengan menggunakan KolmogorovSmirnov adalah kelas Kontrol 0,054 > 0,05 maka data kelas kontrol adalah berdistribusi normal. Untuk kelas eksperimen probabilitas signifikan adalah 0,087 >0,05 maka data kelas eksperimen berdistribusi normal. Artinya, kedua data siap diolah dan diuji perbedaan peningkatan kemampuan pemecahan masalah matematis. Hasil perhitungan homogenistas kedua data, apakah data berasal dari varian yang sama dapat dilihat pada tabel 4 .

Tabel 4. Hasil Uji Homogenitas Varians Pretest Kelas Eksperimen dan Kelas Kontrol

\section{Test of Homogeneity of Variance}

\begin{tabular}{llrrrrr}
\hline & & \multicolumn{2}{c}{$\begin{array}{l}\text { Levene } \\
\text { Statistic }\end{array}$} & df1 & \multicolumn{1}{c}{ df2 } & \multicolumn{1}{c}{ Sig. } \\
\hline pretest & Based on Mean & 5.266 & 1 & 58 & .025 \\
& Based on Median & 3.463 & 1 & 58 & .068 \\
Based on Median and & 3.463 & 1 & 44.653 & .069 \\
with adjusted df & & & & \\
Based on trimmed mean & 4.641 & 1 & 58 & .035 \\
\hline
\end{tabular}

Nilai $F_{\text {hitung }}$ adalah 5,266, jika $F_{\text {hitung }}>F_{\text {tabel, }}$ artinya data tidak berasal dari varians yang sama atau tidak homogen. Jika kita menggunakan probabilitas signifikan dan derajat kebebasan 0,05 dari tabel terlihat bahwa probabilitas signifikan $0,025<0,05$ artinya data tersebut tidak berasal dari data yang memiliki varian yang sama atau tidak homogen. Selanjutnya pengujian perbedaan dua rata-rata data hasil pretes dengan menggunakan statistic parametric yaitu uji-t pada taraf signifikan $\alpha=0,05$ (uji dua pihak $1 / 2 \alpha=0,025$. Jika nilai signifikansi uji-t lebih besar dari taraf signifikannya 0,05 maka $\mathrm{H}_{0}$ diterima. Hasil perhitungan uji perbedaan rata-rata pretes kelas kontrol dan eksperimen disajikan pada tabel 5.

Tabel 5. Uji Perbedaan Rata-Rata

Independent Samples Test

\begin{tabular}{|c|c|c|c|c|c|c|c|c|c|c|}
\hline & & $\begin{array}{r}\text { Levene's ' } \\
\text { Equali } \\
\text { Variar }\end{array}$ & $\begin{array}{l}\text { est for } \\
\text { y of } \\
\text { ces }\end{array}$ & & & & st for Equali & ty of Means & & \\
\hline & & & & & & & & & $\begin{array}{r}95 \% \text { Cor } \\
\text { Interval } \\
\text { Differ }\end{array}$ & $\begin{array}{l}\text { fidence } \\
\text { of the } \\
\text { ence }\end{array}$ \\
\hline & & $\mathrm{F}$ & Sig. & $\mathrm{t}$ & df & $\begin{array}{l}\text { Sig. (2- } \\
\text { tailed) }\end{array}$ & $\begin{array}{c}\text { Mean } \\
\text { Difference }\end{array}$ & $\begin{array}{l}\text { Std. Error } \\
\text { Difference }\end{array}$ & Lower & Upper \\
\hline pretest & $\begin{array}{l}\text { Equal } \\
\text { variances } \\
\text { assumed }\end{array}$ & 5.266 & .025 & 1.194 & 58 & .237 & 4.44444 & 3.72238 & -3.00671 & 11.89560 \\
\hline & $\begin{array}{l}\text { Equal } \\
\text { variances not } \\
\text { assumed }\end{array}$ & & & 1.194 & 46.005 & .239 & 4.44444 & 3.72238 & -3.04830 & 11.93719 \\
\hline
\end{tabular}

Dari table 5, nilai probabilitas signifikansinya adalah $0,025<0,05$ artinya $\mathrm{H}_{0}$ ditolak. Artinya, ada perbedaan antara pretest kelas eksperimen dan kelas kontrol. Nilai $F_{\text {hitung }}$ yang diperoleh adalah 5,266. Setelah diberikan pembelajaran kepada kelas eksperimen dengan pendekatan kontekstual dan kelas kontrol dengan pendekatan konvensional siswa diberi kesempatan untuk menjawab soal akhir (posttest). Posttest terdiri dari data kemampuan pemecahan masalah dan gain ternomalisasi. Berdasarkan data posttest diperoleh skor terendah $\left(\mathrm{X}_{\min }\right)$, skor tertinggi $\left(\mathrm{X}_{\max }\right)$, 
skor rata-rata $\left(\mathrm{X}_{\text {rata-rata }}\right)$, standar deviasi untuk kelas eksperimen dan kelas kontrol, seperti tampak pada tabel 6 .

Tabel 6. Deskripsi Skor Pretest Kelas Eksperimen dan Kontrol

\begin{tabular}{|c|c|c|c|c|c|c|}
\hline \multicolumn{7}{|c|}{ Descriptives } \\
\hline & \multirow{2}{*}{\multicolumn{2}{|c|}{ Kelas }} & \multicolumn{2}{|c|}{ Eksperimen } & \multicolumn{2}{|c|}{ Kontrol } \\
\hline & & & Statistic & Std. Error & Statistic & Std. Error \\
\hline Post- & Mean & & 61.9333 & 3.46740 & 57.8667 & 2.15051 \\
\hline test & 95\% Confidence & Lower Bound & 54.8417 & & 53.4684 & \\
\hline & Interval for Mean & Upper Bound & 69.0250 & & 62.2649 & \\
\hline & $5 \%$ Trimmed Mean & & 60.9259 & & 57.4815 & \\
\hline & Median & & 55.0000 & & 56.0000 & \\
\hline & Variance & & 360.685 & & 138.740 & \\
\hline & Std. Deviation & & 18.99171 & & 11.77880 & \\
\hline & Minimum & & 42.00 & & 40.00 & \\
\hline & Maximum & & 100.00 & & 84.00 & \\
\hline & Range & & 58.00 & & 44.00 & \\
\hline & Interquartile Range & & 33.00 & & 20.00 & \\
\hline & Skewness & & .939 & .427 & .465 & .427 \\
\hline & Kurtosis & & -.522 & .833 & -.684 & .833 \\
\hline
\end{tabular}

Rata-rata pretest pada kelas kontrol lebih tinggi dari pada kelas eksperimen, skor tetinggi dan terrendah pada kelas kontrol lebih rendah dari pada kelas eksperimen. Untuk menguji apakah ada perbedaan dari dua rata-rata antara kelas ekperimen dan kontrol, harus diuji dulu normalitas dan homogenitas data. Uji normalitas dan homogenitas dipakai untuk memenuhi syarat uji dua ratarata dengan menggunakan uji-t atau uji statistik parametrik. Kriteria kesesuaian dihitung dengan menggunakan distribusi $\chi^{2}$ (chi-kuadrat) kriteria pengujiannya dinyatakan dengan membandingkan $\chi^{2}$ yang diperoleh dengan perhitungan (SPSS) dengan $\chi^{2}$ dari tabel distribusi $\chi^{2}$ dengan menggunakan taraf signifikan $\alpha=0,05$ dan derajat kebebasan $\mathrm{dk}$.

Hasil perhitungan $\chi^{2}$ dan harga $\chi_{(1-\alpha)(d k) \text { atau }}^{2} \chi_{\text {tabel }}$ untuk kelas eksperimen dan kelas control, dalam penelitian ini menggunakan uji statistik Kolmogorov-Smirnov pada kedua kelompok, lebih lengkapnya dapat dilihat pada tabel 7.

Tabel 7. Hasil Uji Normalitas Tes Kemampuan Pemecahan Masalah

\section{Tests of Normality}

\begin{tabular}{llrrrrrr}
\hline & & \multicolumn{3}{c}{ Kolmogorov-Smirnov $^{\mathrm{a}}$} & \multicolumn{3}{c}{ Shapiro-Wilk } \\
\cline { 2 - 9 } & kelas & Statistic & \multicolumn{1}{c}{ Df } & \multicolumn{1}{c}{ Sig. } & Statistic & df & \multicolumn{1}{c}{ Sig. } \\
\hline posttest & eks & .232 & 30 & .000 & .840 & 30 & .000 \\
& kon & .157 & 30 & .056 & .956 & 30 & .250 \\
\hline
\end{tabular}

a. Lilliefors Significance Correction

Dari tabel terlihat bahwa probabilitas signifikan dengan menggunakan KolmogorovSmirnov adalah kelas Kontrol 0,056 > 0,05 maka data kelas kontrol adalah berdistribusi normal. Untuk kelas eksperimen probabilitas signifikan adalah 0,000 maka kita lihat nilai $\chi^{2}$ yaitu 0,232. Nilai tabel dengan $\mathrm{dk}=30$ dan taraf signifikansi 0,05 maka $\chi^{2}{ }_{\text {hitung }}<\chi^{2}$ tabel $(13,8)$, artinya data kelas eksperimen berdistribusi normal. Dengan kata lain, kedua data siap diolah dan diuji 
Perbedaan peningkatan kemampuan pemecahan masalah matematis dengan...

perbedaan peningkatan kemampuan pemecahan masalahnya. Hasil perhhitungan homogenitas kedua data, apakah data berasal dari varian yang sama dapat dilihat pada tabel 8 .

Tabel 8. Hasil Uji Homogenitas Varians Posttest Kelas Eksperimen dan Kelas Kontrol

Test of Homogeneity of Variance

\begin{tabular}{llrrrr}
\hline & \multicolumn{1}{c}{$\begin{array}{l}\text { Levene } \\
\text { Statistic }\end{array}$} & df1 & \multicolumn{1}{c}{ df2 } & \multicolumn{1}{c}{ Sig. } \\
\hline posttest & Based on Mean & 5.940 & 1 & 58 & .018 \\
Based on Median & 2.431 & 1 & 58 & .124 \\
$\begin{array}{l}\text { Based on Median and } \\
\text { with adjusted df }\end{array}$ & 2.431 & 1 & 41.156 & .127 \\
Based on trimmed mean & 5.092 & 1 & 58 & .028 \\
\hline
\end{tabular}

Nilai $F_{\text {hitung }}$ adalah 5,940, jika $F_{\text {hitung }}>F_{\text {tabel, artinya data tidak berasal dari varians yang sama }}$ atau tidak homogen. Jika kita menggunakan probabilitas signifikan dan derajat kebebasan 0,018 dari tabel terlihat bahwa probabilitas signifikan $0,018<0,05$ artinya data tersebut tidak berasal dari data yang memiliki varian yang sama atau tidak homogen.

Selanjutnya pengujian perbedaan dua rata-rata data hasil posttest (kemampuan pemecahan masalah) dengan menggunakan statistik parametrik yaitu uji-t pada taraf signifikan $\alpha=0,05$ (uji dua pihak $1 / 2 \quad \alpha=0,025)$. Jika nilai signifikansi melalui uji-t lebih besar dari taraf signifikannya 0,05 maka $\mathrm{H}_{0}$ diterima. Hasil perhitungan uji perbedaan rata-rata pretest kelas kontrol dan eksperimen disajikan pada tabel 9.

Tabel 9. Uji Perbedaan Rata-rata

Independent Samples Test

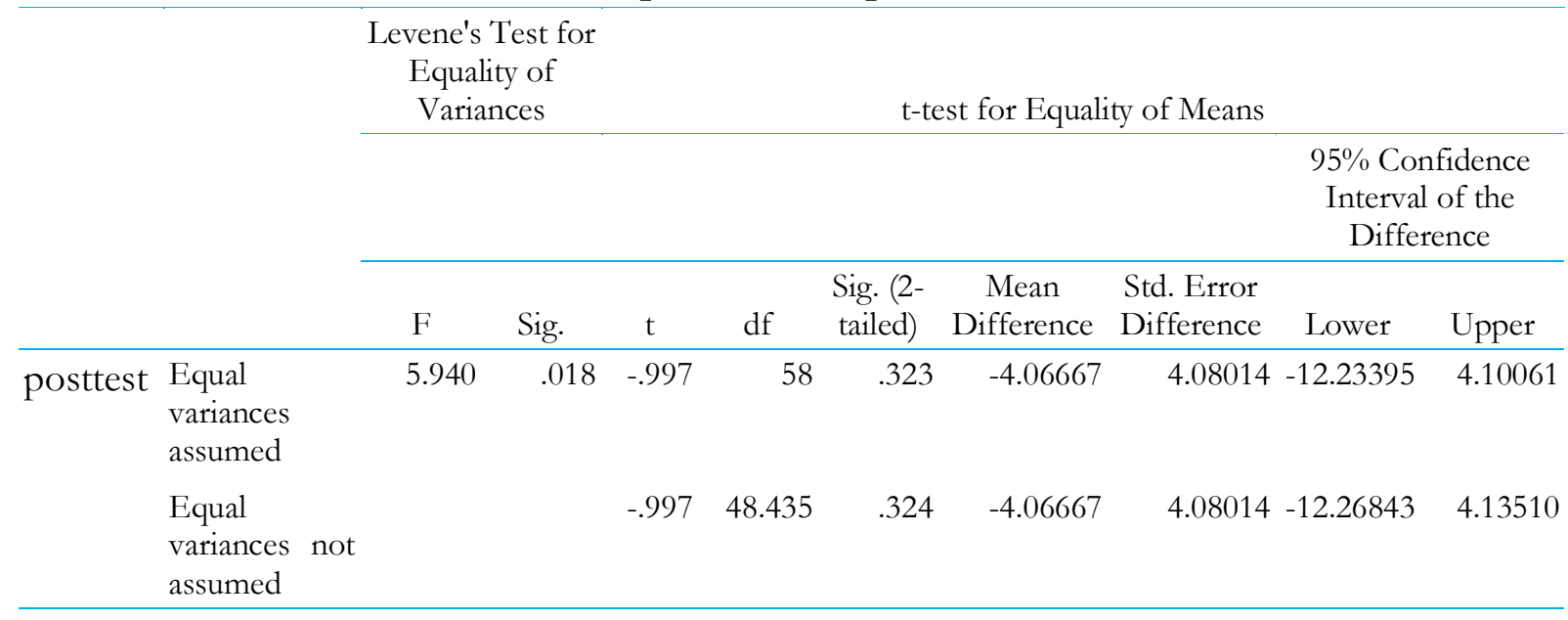

Dari tabel, nilai probabilitas signifikansinya adalah $0,018<0,05$ artinya $\mathrm{H}_{0}$ ditolak. Artinya, ada perbedaan antara posttest (kemampuan pemecahan masalah) kelas eksperimen dan kelas

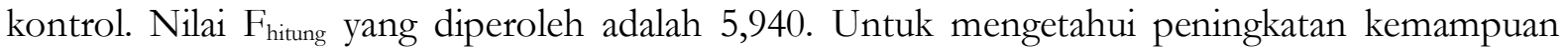
pemecahan masalah yang mengikuti pembelajaran dengan pendekatan kontekstual dan siswa yang mengikuti pembelajaran dengan pendekatan konvensional adalah dengan menghitung gain kedua kelas dengan menggunakan rumus gain ternormalisasi. Hasil perhitungan gain ternormalisasi disajikan pada tabel 10 . 
Tabel 10. Deskripsi Gain Ternormalisasi Tes Kemampuan Pemecahan Masalah Descriptives

\begin{tabular}{|c|c|c|c|c|c|c|}
\hline & \multirow{2}{*}{\multicolumn{2}{|c|}{ Kelas }} & \multicolumn{2}{|c|}{ Eksperimen } & \multicolumn{2}{|c|}{ Kontrol } \\
\hline & & & Statistic & Std. Error & Statistic & Std. Error \\
\hline \multirow[t]{13}{*}{ Gain } & Mean & & .0085 & .22640 & .1688 & .02774 \\
\hline & $95 \% \quad$ Confidence & Lower Bound & -.4545 & & .1121 & \\
\hline & Interval for Mean & Upper Bound & .4715 & & .2255 & \\
\hline & $5 \%$ Trimmed Mean & & .1946 & & .1704 & \\
\hline & Median & & .3143 & & .1676 & \\
\hline & Variance & & 1.538 & & .023 & \\
\hline & Std. Deviation & & 1.24005 & & .15194 & \\
\hline & Minimum & & -4.80 & & -.24 & \\
\hline & Maximum & & 1.00 & & .51 & \\
\hline & Range & & 5.80 & & .75 & \\
\hline & Interquartile Range & & .53 & & .21 & \\
\hline & Skewness & & -2.893 & .427 & -.166 & .427 \\
\hline & Kurtosis & & 8.849 & .833 & .776 & .833 \\
\hline
\end{tabular}

Dari tabel 4.10 terlihat bahwa gain ternormalisasi kelas control lebih besar dibandingkan kelas eksperimen. Gain kedua kelas tergolong gain rendah yaitu $<0,3$. Untuk dapat melihat apakah gain ternormalisasi kelas eksperimen memiliki perbedaan rata-rata signifikan dengan gain ternormalisasi kelas control, maka dilakukan analisis perbedaan rata-rata. Sebelum dilakukan, terlebih dahlu dilakukan uji normalitas dan homogenitas.

Uji normalitas dan homogenitas dipakai untuk memenuhi syarat uji dua rata-rata dengan menggunakan uji-t atau uji statistik parametrik. Hasil perhitungan $\chi^{2}$ dan harga $\chi_{(1-\alpha)(d k)}^{2}$ atau $\chi^{2}$ tabel untuk kelas eksperimen dan kelas control, dalam penelitian ini menggunakan uji statistik Kolmogorov-Smirnov pada kedua kelompok, lebih lengkapnya dapat dilihat pada tabel 11.

Tabel 11. Hasil Uji Normalitas Gain Ternormalisasi Tes Kemampuan Pemecahan Masalah

\section{Tests of Normality}

\begin{tabular}{rlrrrrrr}
\hline & & \multicolumn{3}{c}{ Kolmogorov-Smirnov $^{\mathrm{a}}$} & \multicolumn{3}{c}{ Shapiro-Wilk } \\
\cline { 3 - 9 } & kelas & Statistic & \multicolumn{1}{c}{ Df } & \multicolumn{1}{c}{ Sig. } & Statistic & df & \multicolumn{1}{c}{ Sig. } \\
\hline \multirow{2}{*}{ Gain } & eks & .331 & 30 & .000 & .624 & 30 & .000 \\
& kon & .106 & 30 & $.200^{*}$ & .974 & 30 & .660 \\
\hline
\end{tabular}

a. Lilliefors Significance Correction

*. This is a lower bound of the true significance.

Dari tabel terlihat bahwa probabilitas signifikan dengan menggunakan KolmogorovSmirnov adalah kelas Kontrol 0,106 > 0,05 maka data kelas kontrol adalah berdistribusi normal. Untuk kelas eksperimen probabilitas signifikan adalah 0,000 maka kita lihat nilai $\chi^{2}$ yaitu 0,331 . Nilai tabel dengan $\mathrm{dk}=30$ dan taraf signifikansi 0,05 maka $\chi^{2}$ hitung $<\chi^{2}$ tabel $(13,8)$, artinya data kelas eksperimen berdistribusi normal. Dengan kata lain, kedua data siap diolah dan diuji perbedaan peningkatan kemampuan pemecahan masalahnya. Hasil perhitungan homogenistas kedua data, apakah data berasal dari varian yang sama dapat dilihat pada tabel 12 . 
Perbedaan peningkatan kemampuan pemecahan masalah matematis dengan...

Tabel 12. Hasil Uji Homogenitas Gain Ternormalisasi Kemampuan Pemecahan Masalah Test of Homogeneity of Variance

\begin{tabular}{|c|c|c|c|c|c|}
\hline & & $\begin{array}{l}\text { Levene } \\
\text { Statistic }\end{array}$ & df1 & df2 & Sig. \\
\hline \multirow[t]{4}{*}{ Gain } & Based on Mean & 10.907 & 1 & 58 & .002 \\
\hline & Based on Median & 5.826 & 1 & 58 & .019 \\
\hline & $\begin{array}{l}\text { Based on Median and } \\
\text { with adjusted df }\end{array}$ & 5.826 & 1 & 29.386 & .022 \\
\hline & Based on trimmed mean & 6.725 & 1 & 58 & .012 \\
\hline
\end{tabular}

Nilai $F_{\text {hitung }}$ adalah 10,907, jika $F_{\text {hitung }}>F_{\text {tabel, }}$ artinya data tidak berasal dari varians yang sama atau tidak homogen. Jika kita menggunakan probabilitas signifikan dan derajat kebebasan 0,002 dari tabel terlihat bahwa probabilitas signifikan $0,002<0,05$ artinya data tersebut tidak berasal dari data yang memiliki varian yang sama atau tidak homogen. Selanjutnya pengujian perbedaan dua rata-rata data hasil posttest (kemampuan pemecahan masalah) dengan menggunakan statistik parametrik yaitu uji-t pada taraf signifikan $\alpha=0,05$ (uji dua pihak $1 / 2 \alpha=$ 0,025 . Hasil perhitungan uji perbedaan rata-rata prtes kelas kontrol dan eksperimen disajikan pada tabel 13.

Tabel 13. Hasil Uji Rata-rata Gain Ternormalisasi Kemampuan Pemecahan Masalah

\section{Independent Samples Test}

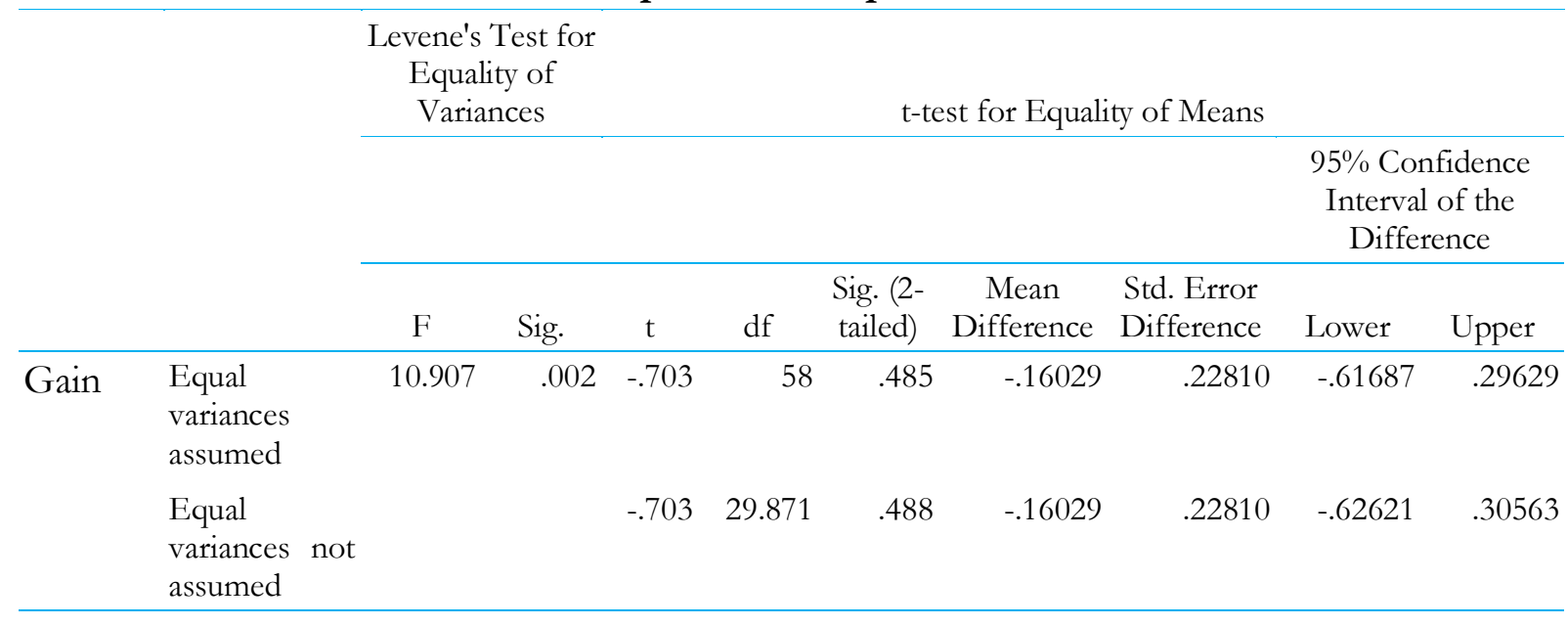

Dari tabel, nilai probabilitas signifikansinya adalah $0,002<0,05$ artinya $\mathrm{H}_{0}$ ditolak. Artinya, ada perbedaan antara Gain ternormalisasi kemampuan pemecahan masalah kelas eksperimen dan kelas kontrol. Nilai $F_{\text {hitung }}$ yang diperoleh adalah 10,907.

Berdasarkan penelitian ini, peningkatan kemampuan pemecahan masalah dengan pendekatan konvensional lebih baik dari pada kontekstual.

\section{KESIMPULAN}

Berdasarkan pembahasan serta temuan selama pembelajaran dengan pendekatan kontekstual, diperoleh beberapa kesimpulan yang merupakan jawaban atas pertanyaan dalam rumusan masalah, kesimpulan tersebut adalah :

1. Rata-rata peningkatan kemampuan pemecahan masalah pada kelas kontrol adalah 0,1688 sementara peningkatan kemampuan pemecahan masalah pada kelas ekperimen adalah 0,0085. Dengan menggunakan uji-t (SPSS), dengan nilai $F_{\text {hitung }}=10,907$ dan taraf signifikan 0,05 
diperoleh probabilitas signifikan $0,002<0,05$ maka dapat disimpulkan ada perbedaan gain ternormalisasi atau peningkatan kemampuan pemecahan masalah dengan pendekatan konvensional dan kontekstual.

2. Berdasarkan rata-rata gain kelas control dan eksperimen, diperoleh peningkatan kelas kontrol dengan pendekatan konvensional lebih tinggi dibandingkan kelas eksperimen dengan pendekatan kontekstual.

3. Perbedaan peningkatan kemampuan pemecahan masalah di kelas konvensional dimungkinkan karena bedanya kemampuan tingkat awal siswa, yang dapat dilihat pada rata-rata pretest masing-masing kelas.

\section{DAFTAR PUSTAKA}

Abdurrahman, M. (2012). Pendidikan Bagi Anak Berkesulitan Belajar, Jakarta: Rineka Cipta.

Afifah, D.S. (2012). Interaksi Belajar Matematika Siswa Dalam Pembelajaran Kooperatif Tipe STAD. Pedagogia, 1 (2), 145-151.

Dicky, T. H. (2019). Rancanfan Eksperimen - Kuasi. Buletin Psikologi. 27 (2). 187 - 203. DOI: 10.22146/buletinpsikologi.38619

Fitrah. (2017). Belajar dan Pembelajaran. Jurnal Kajian Ilmu-ilmu Keislaman, 3 (2) , 333-352.

Nihayah, Z. (2017). Efektivitas Penggunaan Media Tablet dalam Pembelajaran Pendidikan Agama Islam di SMK Muhammadiyah 1 Sukoharjo Tahun Pelajaran 2016-2017. Diakses di: http://eprints.ums.ac.id/54482/13/NASKAH\%20PUBLIKASI.pdf

Ruseffendi, E.T. (2010). Dasar-Dasar Penelitian Pendidikan dan Bidang NonEksakta Lainnya. Bandung: Tarsito.

Sudjana, Nana. 2013. Penilaian Hasil Proses Belajar Mengajar. Bandung: Remaja Rosdakarya

Qurnia, A. S., Y. L. Sekestiyarno, \& Arief A. (2017). Batasan Prasyarat uji Normalitas dan Uji Homogenitas Pada Model Regresi Linear. Unnes Journal of Mathematics. 6 (2). 168-177. DOI: https://doi.org/10.15294/ujm.v6i2.11887 